\title{
ASSIGNMENT OF THE VASCULAR SMOOTH MUSCLE ACTIN GENE ACTSA TO HUMAN CHROMOSOME 10
}

\author{
Hisao Ueyama, ${ }^{1}$ Gail Bruns, ${ }^{2}$ and Naotoshi KandA ${ }^{3}$ \\ ${ }^{1}$ Department of Medical Biochemistry, Shiga University of Medical Science, \\ Seta, Otsu 520-21, Japan \\ ${ }^{2}$ Genetics Division, The Children's Hospital, Boston, MA 02115, U.S.A. \\ 32nd Department of Anatomy, Tokyo Women's Medical College, \\ Shinjuku-ku, Tokyo 162, Japan
}

\begin{abstract}
Summary Human vascular smooth muscle actin gene (ACTSA) was cloned and its unique sequence was used as the hybridization probe for Southern blot analysis of DNAs from 18 rodent-human somatic cell hybrids; the gene was assigned to human chromosome 10. Regional mapping by in situ hybridization showed that the gene is located on the long arm (q22-q24) of the chromosome. Thus, the gene is on a different chromosome from the other four actin genes so far examined.
\end{abstract}

Key Words chromosomal assignment, vascular smooth muscle actin, gene, $A C T S A$, actin, chromosome

\section{INTRODUCTION}

There are at least six actin isoforms in higher vertebrates, i.e., skeletal muscle, cardiac muscle, vascular and enteric smooth muscle, and $\beta$ - and $\gamma$-cytoplasmic actins (Vandekerckhove and Weber, 1978). Their amino acid sequences are very similar; they have a difference of at most 25 amino acids in total of 374-375 amino acid residues (Vandekerckhove and Weber, 1979). Therefore, it is reasonable to postulate one progenitor gene from which genes for these actin species were evolved through multiple duplication. Nevertheless, it is already known that four actin genes so far examined are not linked to each other in the human genome (Gunning et al., 1984; $\mathrm{Ng}$ et al., 1985; Erba et al., 1988). We reported the structure and nucleotide sequence of human vascular smooth actin gene (Ueyama et al., 1984), but its chromosomal location was not determined yet. Here we show that the gene is mapped to human chromosome 10 , which is also different from the location of the other four actin genes.

Received October 30, 1989; revised version received December 18, 1989; Accepted December 28, 1989. 


\section{MATERIALS AND METHODS}

The human gene library for gene walking was kindly supplied by Dr. Takiguchi (Kumamoto University Medical School).

The cell fusion and isolation of rodent-human somatic cell hybrids has been described (Bruns et al., 1979). High-molecular-weight DNAs isolated from 18 hybrid cells $(10 \mu \mathrm{g}$ each) were digested with appropriate enzymes, separated on a $0.7 \%$ agarose gel, and transferred to a nitrocellulose filter (Schleicher \& Schuell, BA85) by the method of Southern (1975). A $2.7 \mathrm{~kb}$ EcoRI-HindIII fragment located around the first exon of human vascular smooth muscle actin gene (Nakano, 1988) was used as the hybridization probe, which was labeled with $\left[\alpha^{-32} \mathrm{P}\right] \mathrm{dCTP}$ by nick-translation to a specific activity of $5 \times 10^{8} \mathrm{cpm} / \mu \mathrm{g}$ of DNA. Hybridization and washing were carried out as described (Taga et al., 1989), and the filter was autoradiographed for 7 days with intensifying screens on Fuji RX X-ray film at $-80^{\circ} \mathrm{C}$.

For in situ hybridization (Kanda et al., 1983), air-dried slides of metaphase cells, stored at least one week in a vacuum dessicator, were denatured in a mixture containing $70 \%$ deionized formamide and $2 \times \mathrm{SSC}(1 \times \mathrm{SSC}=0.15 \mathrm{M} \mathrm{NaCl}-0.015 \mathrm{M}$ sodium citrate) at $65^{\circ} \mathrm{C}$ for $2 \mathrm{~min}$ and then dehydrated successively with 70,80 , and $95 \%$ ethanol. The $2.7 \mathrm{~kb} \mathrm{EcoRI-HindIII} \mathrm{fragment} \mathrm{was} \mathrm{labeled} \mathrm{by} \mathrm{nick-trans-}$ lation to a specific activity of $2 \times 10^{7} \mathrm{cpm} / \mu \mathrm{g}$ of DNA with $\left[{ }^{3} \mathrm{H}\right] \mathrm{dTTP},\left[{ }^{3} \mathrm{H}\right] \mathrm{dCTP}$ and $\left[{ }^{3} \mathrm{H}\right] \mathrm{dATP}$. The labeled probe corresponding to $2.5 \times 10^{5} \mathrm{cpm}$ in $50 \mu \mathrm{l}$ of hybridization mixture $(50 \%$ formamide, $2 \times \mathrm{SSC}, 10 \%$ dextran sulfate, and sheared single-strand DNA at $100 \mu \mathrm{g} / \mathrm{ml}$ ) was added per slide, which was incubated in a humid atmosphere at $42^{\circ} \mathrm{C}$ for $20 \mathrm{hr}$. The slide was washed at $39^{\circ} \mathrm{C}$ with $50 \%$ deionized formamide in $2 \times \mathrm{SSC}$ and then with $2 \times \mathrm{SSC}$, and dried with ethanol before being dipped in Kodak NTB-2 emulsion.

\section{RESULTS AND DISCUSSION}

Human vascular smooth muscle actin gene was already cloned (Ueyama et al., 1984; Nakano, 1988; Kamada et al., 1989), but we further picked up 5'- and 3'flanking region-containing clones. The results are summarized in Fig. 1. We have walked from the initial gene $(18 \mathrm{~kb}) 18 \mathrm{~kb}$ upstream and $13 \mathrm{~kb}$ downstream.

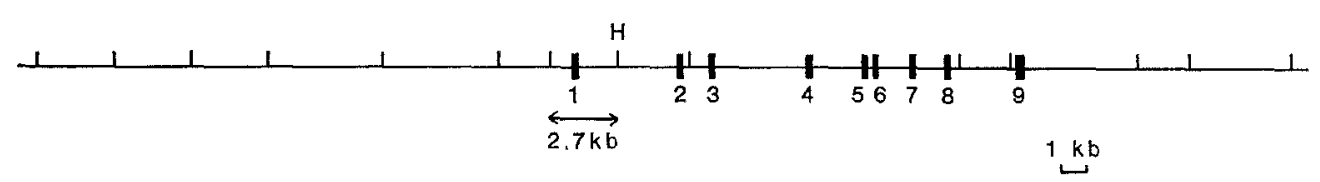

Fig. 1. Map of the human vascular smooth muscle actin gene. The $2.7 \mathrm{~kb}$ EcoRI-HindIII fragment indicated was used as the hybridization probe. Vertical bars, EcoRI sites; H, HindIII site. The exons are designated 1 through 9. 
By using a fragment derived from the 3'-flanking region, we detected a TaqI RFLP (Ueyama and Ohsugi, manuscript in preparation). The region used as the hybridization probe in this study (the $2.7 \mathrm{~kb}$ EcoRI-HindIII fragment) is also shown in Fig. 1.

When the labeled probe for vascular smooth muscle actin gene was hybridized to an EcoRI-digest of human peripheral blood leukocyte DNA, a $5.5 \mathrm{~kb}$ band was detected. No hybridizing band was obtained in rodent DNAs. Southern blot analysis of the panel of 18 rodent-human hybrid DNAs digested with BglII, HindIII, or BamHI showed that the signal for human vascular smooth muscle actin gene was in a good correlation with the presence of human chromosome 10 (Table 1).

When the same DNA probe but labeled with ${ }^{3} \mathrm{H}$ was used for in situ hybridization of human chromosomes, the autoradiographic grains were concentrated on the long arm of chromosome 10 (q22-q24, Fig. 2). Thus, the structural gene for vascular smooth muscle actin was found to be on a different chromosome from the other four actin genes so far examined.

The actin gene family has been suggested to be dispersed throughout the human genome (Soriano et al., 1982); every chromosome was labeled in situ with an actin gene-specific probe. Among about 20 human actin genes (Humphries et al., 1981), the skeletal actin gene was assigned to human chromosome 1 (p21-qter) (Gunning et al., 1984), cardiac actin gene to chromosome 15 (q11-qter) (Gunning et al., 1984), $\beta$-actin gene to chromosome 7 (pter-q22) (Hg et al., 1985), $\gamma$-actin gene to chromosome 17 (Erba et al., 1988), and some of actin pseudogenes to chromosomes 5, 7, 18 , and $\mathrm{X}(\mathrm{Ng}$ et al., 1985). It is of interest that the genes for two very closely related cytoplasmic actins, which have only a 4-amino acid difference (Vadekerckhove and Weber, 1979) and are co-expressed in many tissues (Vandekerckhove and

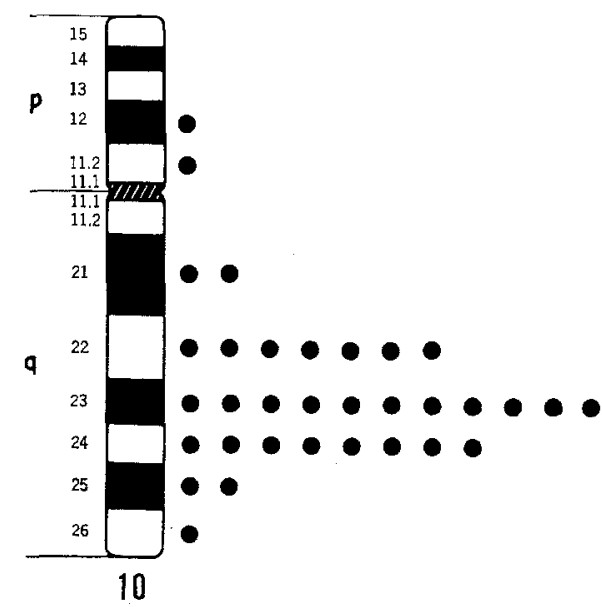

Fig. 2. In situ hybridization of human vascular smooth muscle actin gene probe to human chromosome 10. A clustering of autoradiographic grains over the long arm (q22-q24) is apparent. 
Table 1. Distribution of vascular smooth muscle actin gene

\begin{tabular}{|c|c|c|c|c|c|c|c|c|c|c|c|c|}
\hline \multirow{2}{*}{ Cell hybrids } & \multirow{2}{*}{$A C T S A$} & & & & & & & & & \multicolumn{3}{|c|}{ Presence of } \\
\hline & & 1 & 2 & 3 & 4 & 5 & 6 & 7 & 8 & 9 & 10 & 11 \\
\hline G35F5 & - & \pm & - & + & + & - & + & - & - & + & - & + \\
\hline G35C4 & - & - & - & - & - & - & + & - & - & $R$ & - & - \\
\hline $\mathrm{G} 35 \mathrm{Cl}$ & + & - & - & $\mathrm{R}$ & - & - & $\mathrm{R}$ & + & - & - & + & + \\
\hline G35D3 & - & - & $\mathrm{P}$ & - & - & - & - & + & + & + & - & - \\
\hline G35E4 & - & - & - & - & + & - & - & - & - & + & - & - \\
\hline G35A4 & - & + & - & + & + & - & + & - & + & + & - & - \\
\hline G35A2 & - & - & - & + & + & - & + & - & - & - & - & + \\
\hline G35F1 & + & + & - & - & + & + & - & - & + & - & + & - \\
\hline G56F3 & - & - & - & - & - & - & + & - & - & - & - & - \\
\hline G89E5 & - & - & - & - & - & - & - & - & - & - & - & - \\
\hline G95A4 & - & - & - & - & - & - & - & - & - & - & - & - \\
\hline G35B5 & - & - & - & - & - & - & $\mathrm{R}$ & + & - & - & - & + \\
\hline G35D5 & + & + & + & + & - & - & + & + & - & - & + & - \\
\hline G24A4 & - & + & + & - & - & + & + & + & - & + & - & + \\
\hline G24A9 & + & - & + & - & + & - & + & - & + & t & + & - \\
\hline G24B2 & + & - & - & + & - & + & - & + & - & + & + & - \\
\hline G17-11 & + & - & - & - & - & + & + & + & - & - & + & - \\
\hline $\mathrm{G} 13 \mathrm{C} 2$ & + & - & + & ND & + & + & - & + & - & + & + & + \\
\hline
\end{tabular}

$\mathrm{P}$, short arm only; R, rearrangement; ND, not determined; ACTSA, vascular smooth muscle human-mouse cell hybrids.

Weber, 1981; Erba et al., 1988), are on different chromosomes. Our data presented here indicate that the human vascular smooth muscle actin gene is not linked to these actin genes but on a different chromosome. Their chromosomal dispersion through transposition or translocation must have occurred after a tandem duplication and such a chromosomal dispersion of duplicated copies might be correlated with their different expression in a tissue-specific manner.

Acknowledgments We are grateful to Prof. Ueda for his advice during this work and Dr. Takiguchi for supplying his human gene library. We thank Miss Ohsugi for her technical assistance.

This work was supported in part by a Grant-in-Aid (No. 61570122) for Scientific Research from the Ministry of Education, Science and Culture of Japan.

\section{REFERENCES}

Bruns, G.A., Mintz, B.J., Leary, A.C., Regina, V.M. and Gerald, P.S. 1979. Human lysosomal genes: arysulfatase A and beta-galactosidase. Biochem. Genet. 17: 1031-1059.

Erba, H.P., Eddy, R., Shows, T., Kedes, L. and Gunning, P. 1988. Structure, chromosomal location, and expression of the human $\gamma$-actin gene: differential evolution, location, and expression 
and human chromosomes in human-rodent cell hybrids.

\begin{tabular}{|c|c|c|c|c|c|c|c|c|c|c|c|}
\hline \multicolumn{12}{|c|}{ human chromosomes } \\
\hline 12 & 13 & 14 & 15 & 16 & 17 & 18 & 19 & 20 & 21 & 22 & $\mathrm{X}$ \\
\hline- & + & + & - & $t$ & + & + & + & \pm & + & + & + \\
\hline+ & - & + & - & - & - & \pm & + & + & + & - & - \\
\hline$P$ & - & + & + & + & - & + & + & - & - & + & - \\
\hline- & - & - & - & + & + & - & + & + & + & + & - \\
\hline- & - & - & + & - & - & - & + & - & - & - & - \\
\hline- & - & + & - & + & - & - & + & + & + & - & + \\
\hline- & - & + & - & - & - & - & + & + & + & + & \pm \\
\hline+ & - & $t$ & - & - & - & + & + & + & + & - & + \\
\hline+ & - & - & - & - & - & - & - & + & + & - & + \\
\hline- & - & - & - & - & - & - & - & - & - & - & + \\
\hline- & - & - & - & - & - & - & + & - & - & - & + \\
\hline $\mathrm{P}$ & + & - & - & - & + & - & + & + & - & - & + \\
\hline- & + & + & + & + & + & + & + & + & - & + & - \\
\hline+ & + & + & + & - & - & - & + & - & + & - & + \\
\hline- & + & + & + & - & + & + & + & + & + & - & + \\
\hline- & + & + & + & + & - & - & + & - & + & + & + \\
\hline+ & + & + & - & - & + & + & + & + & + & - & - \\
\hline- & + & + & + & + & ND & + & - & + & + & ND & + \\
\hline
\end{tabular}

actin gene. G35F5 through G35D5 are human-Chinese hamster cell hybrids and the others are

of the cytoskeletal $\beta$ - and $\gamma$-actin genes. Mol. Cell. Biol. 8: 1775-1789.

Gunning, P., Ponte, P., Kedes, L., Eddy, R. and Shows, T. 1984. Chromosomal location of the co-expressed human skeletal and cardiac actin genes. Proc. Natl. Acad. Sci. U.S.A. 81: 18131817.

Humphries, S.E., Whittall, R., Minty, A., Buckingham, M. and Williamson, R. 1981. There are approximately 20 actin genes in the human genome. Nucleic Acids Res. 9: 4895-4908.

Kamada, S., Nakano, Y. and Kakunaga, T. 1989. Structure of $3^{\prime}$ downstream segment of the human smooth muscle (aortic type) $\alpha$-actin-encoding gene and isolation of the specific DNA probe. Gene 84: 455-462.

Kanda, N., Schreck, R., Alt, F., Bruns, G., Baltimore, D. and Latt, S. $1983 . \quad$ Isolation of amplified DNA sequences from IMR-32 human neuroblastoma cells: facilitation by fluorescence-activated flow sorting of metaphase chromosomes. Proc. Natl. Acad. Sci. U.S.A. 80: 4069-4073.

Nakano, Y. 1988. Analysis of 5' upstream region of the human aorta type smooth muscle actin gene. Med. J. Osaka Univ. Jpn. Ed. (in Japanese) 40:283-292.

Ng, S.-Y., Gunning, P., Eddy, R., Ponte, P., Leavitt, J., Shows, T. and Kedes, L. 1985. Evolution of the functional human $\beta$-actin gene and its multi-pseudogene family: conservation of noncoding regions and chromosomal dispersion of pseudogenes. Mol. Cell. Biol. 5: 27202732.

Soriano, P., Szabo, P. and Bernardi, G. 1982. The scattered distribution of actin genes in the mouse 
and human genomes. EMBO J. 1: 579-583.

Southern, E.M. 1975. Detection of specific sequences among DNA fragments separated by gel electrophoresis. J. Mol. Biol. 98: 503-517.

Taga, T., Shirahase, W., Shimada, M., Kurokawa, K. and Ueyama, H. 1989. Restriction fragment length polymorphisms on the q24-q28 region of X chromosome among Japanese population. Jpn. J. Human Genet. 34: 123-128.

Ueyama, H., Hamada, H., Battula, N. and Kakunaga, T. 1984. Structure of a human smooth muscle actin gene (aortic type) with a unique intron site. Mol. Cell. Biol. 4: 1073-1078.

Vandekerckhove, J. and Weber, K. 1978. At least six different actins are expressed in a higher mammal: an analysis based on the amino acid sequence of the amino-terminal tryptic peptide. J. Mol. Biol. 126: 783-802.

Vandekerckhove, J. and Weber, K. 1979. The complete amino acid sequence of actins from bovine aorta, bovine heart, bovine fast skeletal muscle, and rabbit slow skeletal muscle. A proteinchemical analysis of muscle actin differentiation. Differentiation 14: 123-133.

Vandekerckhove, J. and Weber, K. 1981. Actin typing on total cellular extracts. A highly sensitive protein-chemical procedure able to distinguish different actins. Eur. J. Biochem. 113: 595-603. 